\title{
Endogenous polyamine content and photosynthetic performance under hypo-osmotic conditions reveal Cymodocea nodosa as an obligate halophyte
}

\author{
M. Zarranz Elso*, P. García-Jiménez, R. R. Robaina \\ Departamento de Biología, Facultad de Ciencias del Mar, Universidad de Las Palmas de Gran Canaria, \\ 35017 Las Palmas de Gran Canaria, Canary Islands, Spain
}

\begin{abstract}
Endogenous polyamine (PA) content in the seagrass Cymodocea nodosa was monitored at different embryo and seedling developmental stages. Total PA concentration, including putrescine (Put), spermidine (Spd) and spermine (Spm), and the Put $(\mathrm{Spm}+\mathrm{Spd})^{-1}$ ratio decreased during embryo development, from the immature fruit to the mature seed stage (with a sharp decline in the free PA fraction), and subsequently increased during germination and seedling development from the cotyledon to seedling stage, indicating an important role during zygotic embryogenesis and seed germination. In particular, total levels of Put and Spm significantly decreased from the fruit to the mature seed, to be restored after germination. Spd levels remained constant during all the developmental stages studied. When seedlings were subjected to hypoosmotic stress (i.e. salinity decrease from 36 to $5 \mathrm{psu}$ ), fluorescence levels decreased, reaching a minimum photochemical efficiency $\left(F_{\mathrm{v}} / F_{\mathrm{m}}\right)$ at 5 psu $(0.582 \pm 0.025$, mean $\pm \mathrm{SE})$, indicating that seedlings were under high stress. Contrary to expectations, this was followed by a slight decrease in total PA content (showing a significance difference between 5 psu and higher salinities in bound-insoluble PA) and the accumulation of the PA cadaverine (Cad) at 5 psu (indicating cell death), which revealed the inability of this species to face the abiotic stress promoted by long-term salinity decrease. These 2 physiological indicators may suggest that $C$. nodosa is an obligate halophyte because it requires an environment with relatively high and stable salinity for its survival. Moreover, exogenous application of Spd significantly improved $F_{\mathrm{v}} / F_{\mathrm{m}}$ values at the lowest salinity treatment (5 psu: $0.670 \pm 0.012$ ), which suggests a protective role of Spd in maintaining the photosynthetic apparatus of $C$. nodosa seedlings under long-term hypo-osmotic stress.
\end{abstract}

KEY WORDS: Cymodocea nodosa $\cdot$ Fluorescence $\cdot$ Obligate halophyte $\cdot$ Polyamines $\cdot$ Hypo-salinity $\cdot$ Seagrass

Resale or republication not permitted without written consent of the publisher

\section{INTRODUCTION}

Seagrasses are marine angiosperms that have evolved from terrestrial ancestors (Kuo \& den Hartog 2001). A total of 4 families, 64 species and 12 genera have been recognized, distributed in all regions of the earth except for Antarctica (Kuo \& den Hartog 2006). Due to their ability to survive and reproduce in a saline environment, they have been defined as halophytes (Flowers \& Colmer 2008). These marine plants live from open waters to estuaries, from the shore to $40 \mathrm{~m}$ deep, and withstand a wide rage of salinities (from 0 to $70 \mathrm{psu}$, Touchette 2007). Thus, some species are considered to be euryhaline, since they form healthy stands under a wide range of salinities, such as Ruppia marítima or Zostera noltii (Murphy et al. 2003, Fernández Torquemada \& Sánchez Lizaso 2006), while others, such as Thalassia testudinum or Posidonia oceanica, are considered stenohaline as they live in more stable environments with optimum growth around fully marine salinity levels (Kahn \& Durako 2006, Sánchez Lizaso et al. 2008). 
In general, sudden and sustained salinity changes can alter important plant biochemical and physiological processes, leading to a reduction of seagrass vitality and often ending in plant mortality. Many studies have focused on how hyper-saline conditions resulting from brine discharges from seawater desalination plants affect seagrass meadows (Fernández Torquemada \& Sánchez Lizaso 2006, Sánchez Lizaso et al. 2008, Pagès et al. 2010). A more limited number of studies have focused on the effects of hypo-salinity on seagrass prairies, even though the decrease in salinity can occur naturally (up to 3 psu following heavy rainfall; Chollett et al. 2007) or due to anthropogenic factors (freshwater runoff; Irlandi et al. 2002, Kahn \& Durako 2006). In addition, the decrease in the salinity of the Mediterranean Sea as a result of heavy rains and freshwater runoff has served to justify the germination of Cymodocea nodosa seeds by several authors (Caye \& Meinesz 1986, Caye et al. 1992). More recent work has documented that optimal seed germination in $C$. nodosa seeds occurrs at $50 \%$ of ambient salinity (36 psu) under laboratory conditions, although equivalent effects may be obtained with salinity as low as 11 psu (Zarranz et al. 2010a). Thus hypo-saline conditions play an important role during the life cycle of C. nodosa.

Photosynthesis and respiration are often inhibited in aquatic plants exposed to extreme hypo- or hyperosmotic conditions (Ralph 1998, Hellblom \& Björk 1999, Murphy et al. 2003, Fernández-Torquemada \& Sánchez-Lizaso 2005, Kahn \& Durako 2006, Koch et al. 2007, Touchette 2007, Pagès et al. 2010), probably due to a decline in photosynthetic pigments, a change in chloroplast structure, disruptions of linear electron flow through photosystems or inhibition of key photosynthetic enzymes (Demetriou et al. 2007, Touchette 2007). Measurements of chlorophyll fluorescence has become an accepted technique for the assessment of plant stress (Ralph 1998, 1999) and was used in the present study to determine the physiological status of Cymodocea nodosa seedlings under different salinity conditions.

Polyamines (PAs) are low molecular weight aliphatic amines, almost fully charged at physiological $\mathrm{pH}$, that are found in all living organisms. In plant cells, the diamine putrescine (Put), the triamine spermidine (Spd) and the tetramine spermine (Spm) are synthesized naturally and are derived from the amino acids arginine and ornithine. These PAs occur in free form, as flexible aliphatic chains, and in conjugated form, soluble when bound to low molecular weight compounds (cinnamic acid, caffeic, etc.) or insoluble when bound to macromolecules (hemicellulase, lignin, proteins and nucleic acids). They are primarily detected in actively growing tissues, but their concentration may vary markedly depending on plant species, organ, tissue, and also developmental stage. PAs are known to be essential for growth and development, and they are involved in a wide variety of biological processes, such as cell division and elongation, embryogenesis, reproductive organ development, root growth, flower and fruit development, as well as replication, transcription, translation, membrane and cell wall stabilization, chromatin organization, ribosome biogenesis and programmed cell death (reviewed by Pal Bais \& Ravishankar 2002, Kaur-Sawhney et al. 2003, Kuznetsov et al. 2006, Pang et al. 2007, Baron \& Stasolla 2008, Hussain et al. 2011). PAs are also implicated in the response of plants to biotic and abiotic stresses, such as pathogen attack, mineral nutrient deficiencies, temperature stress, osmotic stress, oxidative stress, drought, salinity and/or metal toxicity (Kuznetsov et al. 2006, Mutlu \& Bozcuk 2007, Yiu et al. 2009, Zhou \& Yu 2010, Amooaghaie 2011, Amooaghaie \& Moghym 2011, Gupta \& Gupta 2011, Hussain et al. 2011, Yang et al. 2011). Changes in the endogenous PA content or in their distributional patterns (from the free to the bound fraction, and vice versa) have also been traditionally used in physiological studies as a developmental marker or as a stress indicator.

Although the ecological importance of seagrass ecosystems has been widely documented (Orth et al. 2006), knowledge about their physiology at the individual level is relatively limited compared to that available on terrestrial plants. A barely known aspect is the role of plant growth regulators (PGRs), which have been traditionally used to stimulate plant development (Terrados Muñoz 1995, Balestri \& Bertini 2003, García-Jiménez et al. 2006, Zarranz et al. 2010b). Relatively few studies have focused on the functionality of PGR and their endogenous content in these segrasses. In relation to PAs, only Marián et al. (2000), using thin-layer chromatography, showed the presence of these growth factors in all tissues of Cymodocea nodosa, observing a greater accumulation in the apical section of the rhizome, which was likely because it was a meristematic zone with actively growing tissue. To date there are no known studies determining the evolution of the endogenous PA content during either seed ontogeny or abiotic stress in seagrasses.

In the present study, we determined the evolution of endogenous PA content during the early stages of seed and seedling development in the marine angiosperm Cymodocea nodosa. Because C. nodosa seed germination occurs naturally under low salinity, we 
aimed to study the effects of a long-term decrease in salinity on seedling development using 2 physiological parameters indicative of their health status: chlorophyll fluorescence and endogenous PA content.

\section{MATERIALS AND METHODS}

\section{Plant material}

Cymodocea nodosa fruit and seeds were collected by SCUBA diving from a natural meadow located on the southeastern coast of Gran Canaria. Once in the laboratory, seeds were sterilized and germinated in axenic Magenta vessels (Sigma) containing sand and modified Provasoli's enriched seawater (PES) medium (Provasoli 1968, García Jiménez et al. 2006) as described in Zarranz et al. (2010a).

Four developmental stages during zygotic embryogenesis and seed germination were chosen for the determination of endogenous PA content in Cymodocea nodosa: (1) fruit containing the immature embryo with epicarp (Fig. 1a), (2) seed containing the mature embryo without epicarp (Fig. 1b), (3) cotyledonary stage (15 d after germination) (Fig. 1c) and (4) developed seedling (1 mo after germination) (Fig. 1d).

\section{Hypo-salinity and PA treatment}

One month after germination, Cymdocea nodosa seedlings were exposed to different salinity levels (5, 11, 18 and 36 psu as salinity in nature) for $15 \mathrm{~d}$. Each Magenta vessel was considered as the experimental unit; hence 3 vessels with 2 seedlings each were employed for each treatment.

To determine the effect of exogenous PA application on the stabilization of the photosynthetic apparatus, salinity treatments $(5,11,18$ and 36 psu as salinity in nature) were repeated, and Spd was added to each Magenta vessel at a final concentration of $10^{-6} \mathrm{M}$. The polyamine Spd was selected for this experiment because it was the most stable PA during seedling development (see 'Results', Fig. 2A-D), which confers it as an apparently homeostatic feature.

\section{Extraction and dansylation of PAs for HPLC measurements}

Plant material from different developmental stages $(600 \mathrm{mg})$ and seedlings from hypo-salinity treatments (i.e. 2 seedlings from each Magenta vessel) were powdered in a small mortar with liquid nitrogen. PAs were extracted in $1.5 \mathrm{ml}$ of $5 \%$ percloric acid (PCA), and centrifugated at $9000 \mathrm{~g}$ for $20 \mathrm{~min}$ at $6^{\circ} \mathrm{C}$. The supernatant, containing free acid-soluble ('free') and bound acid-soluble ('bound-soluble') PAs, and the pellet, containing bound acid-insoluble ('boundinsoluble') PAs, were separated. Part of the supernatant $(260 \mu \mathrm{l})$ was kept frozen for the subsequent dansylation of the free PA fraction. To analyse the bound fraction, $300 \mu \mathrm{l}$ of the supernatant or pellet fraction (after the pellet was re-suspended in $1 \mathrm{M}$ $\mathrm{NaOH}_{i} 600 \mathrm{mg}$ fresh weight:1.5 ml) were mixed with $300 \mu \mathrm{l}$ of $\mathrm{HCl}(12 \mathrm{M})$ in separate vials, sealed with a flame and heated at $100^{\circ} \mathrm{C}$ for $20 \mathrm{~h}$. After hydrolization was completed, the samples were filtered, dried
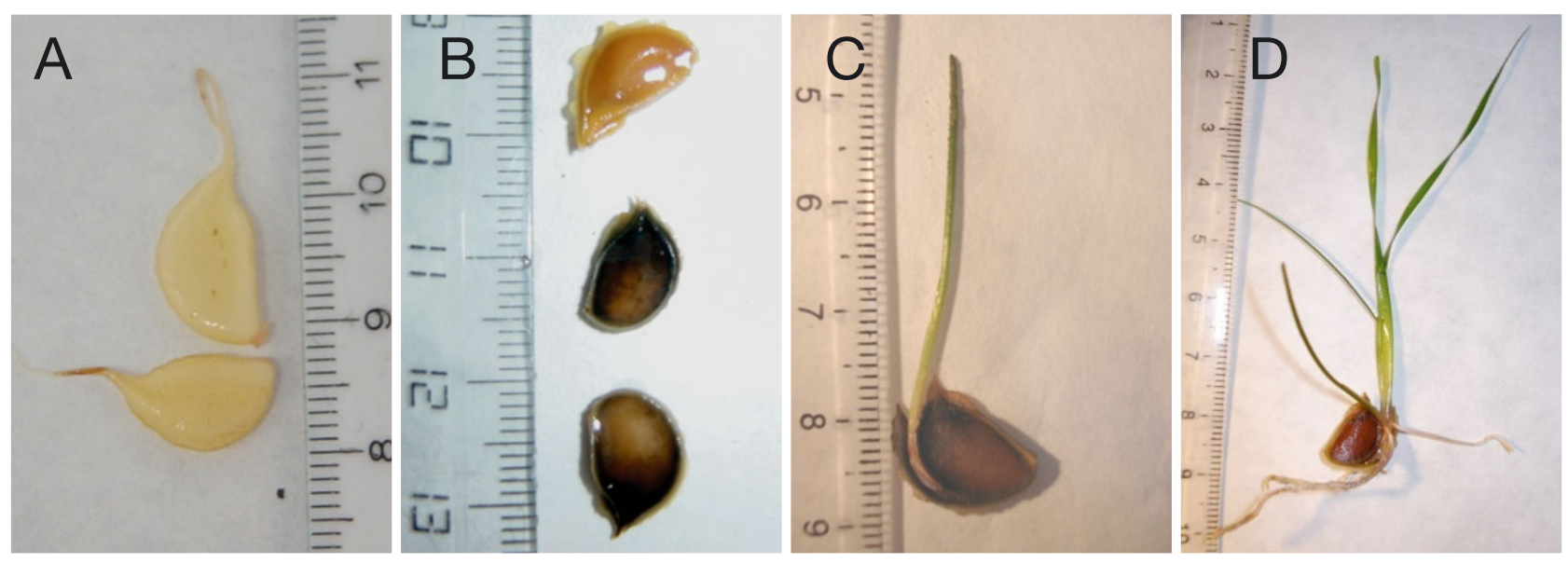

Fig. 1. Cymodocea nodosa. Developmental stages during zygotic embryogenesis and seed germination: (A) fruit containing the immature embryo with epicarp, (B) seed containing the mature embryo without epicarp, (C) cotyledonary stage (15 d after germination), and (D) developed seedling (1 mo after germination) 
in a vacuum, and re-dissolved in $260 \mu \mathrm{l}$ of $5 \%$ PCA to be dansylated (Marián et al. 2000). Each PA fraction (260 $\mu \mathrm{l}$ of $5 \%$ PCA) was mixed with $40 \mu \mathrm{l}$ of $0.05 \mathrm{mM}$ diamino heptane (HTD) as an internal standard (Sacramento et al. 2007). The subsequent dansylation process and quantification by HPLC was carried out as described in Marcé et al. (1995). PAs were finally analysed in a $5 \mu \mathrm{m}$ reverse-phase column (Varian C-18), and PA peaks were detected using a fluorescence detector (Varian ProStar) at 365 (excitation) and $510 \mathrm{~nm}$ (emission). Four PA standards (Sigma Chemical) of cadaverine (Cad), Put, Spd and Spm $(0.05 \mathrm{M})$ were prepared with $220 \mu \mathrm{l}$ of PCA (5\%) and $40 \mu \mathrm{l}$ of HTD (0.05 M). Peak areas and retention times were measured by comparison with standard PAs.

\section{Chlorophyll fluorescence determination}

Fifteen days after hypo-salinity and PA treatment of Cymodocea nodosa seedlings, the maximum photochemical quantum yield of Photosystem II (PSII) measured by the $F_{\mathrm{v}} / F_{\mathrm{m}}$ ratio, was determined on dark adapted leaves (30 min) at room temperature with a JUNIOR-PAM chlorophyll fluorometer (Walz) (Maxwell \& Johnson 2000, Ritchie 2006). $F_{\mathrm{v}} / F_{\mathrm{m}}$ is the ratio of variable fluorescence to maximal fluorescence $\left(F_{m}-F_{o} / F_{m}\right)$, where $F_{o}$ is the minimum fluorescence level when all antenna pigment complexes associated with the photosystem are assumed to be open (dark adapted) and $F_{m}$ corresponds to the maximum chlorophyll fluorescence level when photosystem II reaction centers are closed by a strong light pulse (relative units). We determined the $F_{\mathrm{v}} / F_{\mathrm{m}}$ ratio from the middle of each seedling leaf (average of 3 leaves) (Ralph 1998, Beer et al. 2006, Pagès et al. 2010), taking a total of 6 quantum efficiency measurements per Magenta vessel (saturating pulse intensity and width set to $10000 \mu \mathrm{mol} \mathrm{m} \mathrm{m}^{-2} \mathrm{~s}^{-1}$ and $0.6 \mathrm{~s}$ respectively).

\section{Statistical analysis}

The results were obtained for each treatment in 3 independent experiments. The mean values were calculated and were subjected to a 1-way ANOVA test, followed by Tukey's HSD and Dunnett's T3 post hoc tests or non-parametric Mann-Whitney (Wilcoxon) $W$ tests (SPSS). Student's $t$-tests (unpaired 2-sample) were used to determine significant differences between endogenous PA content in different developmental stages (i.e. fruit vs. seed and cotyledon vs. seedling; $\mathrm{p} \leq$ 0.05).

\section{RESULTS}

\section{PA levels during seed and seedling development}

In general, total PA concentration and the Put $(\mathrm{Spm}+\mathrm{Spd})^{-1}$ ratio decreased during embryo development from immature fruit to the mature seed stage, with a sharp decline in the free PA fraction, and subsequently increased during germination and seedling development, from the cotyledon to the seedling stage (Table 1).

In particular, total Put and Spm concentration significantly decreased during seed maturation, while total Spd remained constant (Fig. 2A). This pattern was shown in the bound-soluble and -insoluble PA fractions (Fig. 2C,D), while total Put, Spd and Spm concentration decreased from immature fruit to mature seed (Fig. 2B). During seed germination, total concentrations of Put and Spm significantly increased between 15 (cotyledon stage) and $30 \mathrm{~d}$ (seedling stage). A significant difference was also detected in bound-soluble and -insoluble Put and Spm fractions (Fig. 2C,D), while all Spd fractions remained constant (Fig. 2A-D).

Table 1. Cymodocea nodosa. Mean $( \pm \mathrm{SE})$ polyamine $(\mathrm{PA})$ concentration, in total and by fraction, and Put $(\mathrm{Spm}+\mathrm{Spd})^{-1} \mathrm{ratio}$ during 4 different stages of development determined in 3 independent experiments. Significant differences tested with unpaired 2 -sample $t$-tests (fruit vs. seed and cotyledon vs. seedling). Put: putrescine; Spd: spermidine; Spm: spermine. ${ }^{*} p \leq 0.05$

\begin{tabular}{|c|c|c|c|c|c|}
\hline \multirow{2}{*}{$\begin{array}{l}\text { Developmental } \\
\text { stage }\end{array}$} & \multicolumn{4}{|c|}{ - PA conc. $\left(\mu \mathrm{mol} \mathrm{PA} \mathrm{g}^{-1}\right.$ fresh wt) } & \multirow[t]{2}{*}{ Put $(\mathrm{Spd}+\mathrm{Spm})^{-1}$} \\
\hline & Total & Free & Bound-soluble & Bound-insoluble & \\
\hline Fruit & $0.6448 \pm 0.024$ & $0.2463 \pm 0.010$ & $0.2900 \pm 0.047$ & $0.1085 \pm 0.022$ & 0.9739 \\
\hline Seed & $0.4405 \pm 0.058^{*}$ & $0.0804 \pm 0.008^{*}$ & $0.2777 \pm 0.037$ & $0.0824 \pm 0.021$ & $0.1185^{*}$ \\
\hline Cotyledon & $0.5596 \pm 0.032$ & $0.1839 \pm 0.030$ & $0.3084 \pm 0.011$ & $0.0672 \pm 0.012$ & 0.8007 \\
\hline Seedling & $0.7702 \pm 0.062^{*}$ & $0.2628 \pm 0.025$ & $0.4233 \pm 0.048$ & $0.0841 \pm 0.008$ & 1.1241 \\
\hline
\end{tabular}



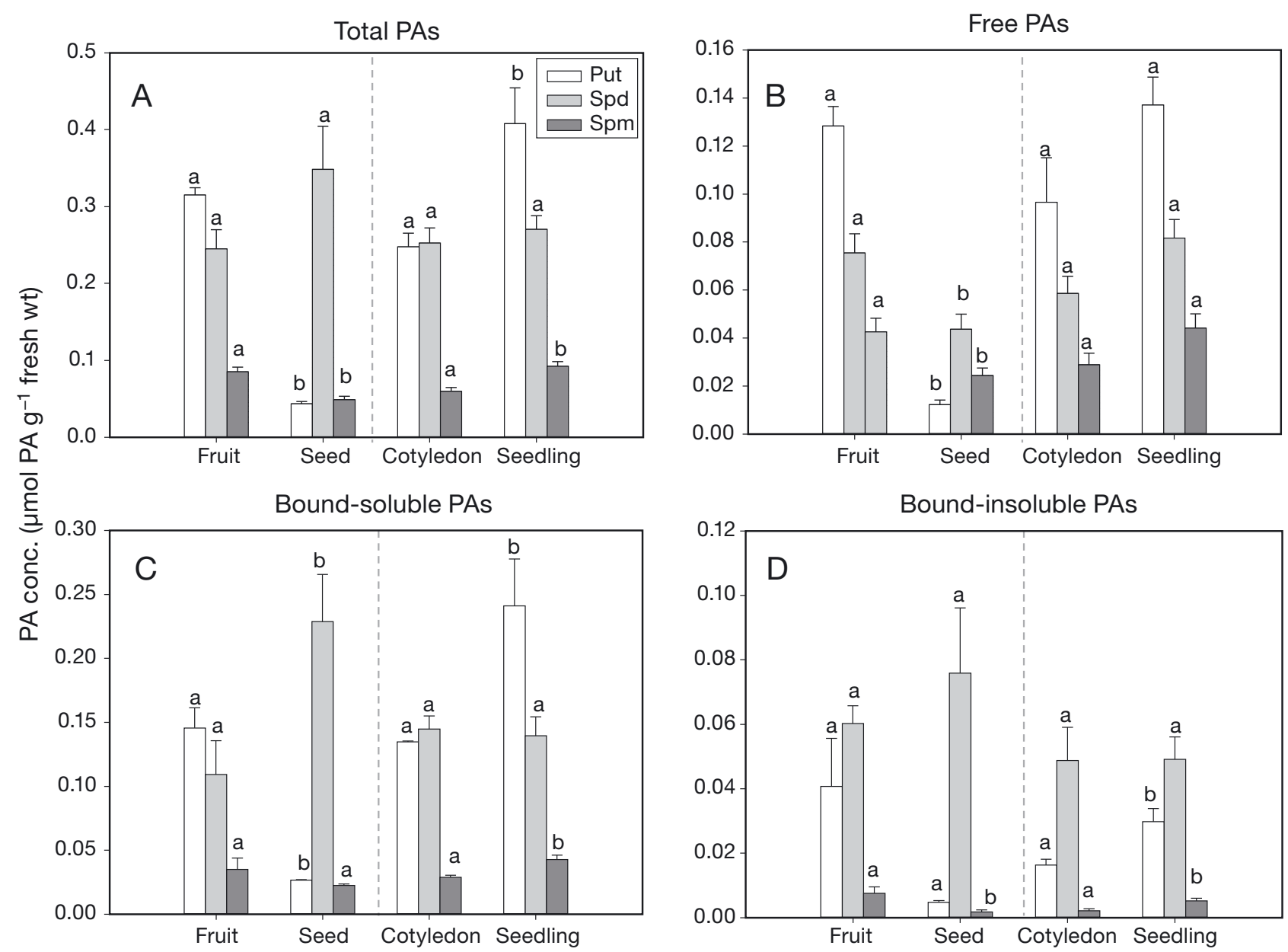

Developmental stage

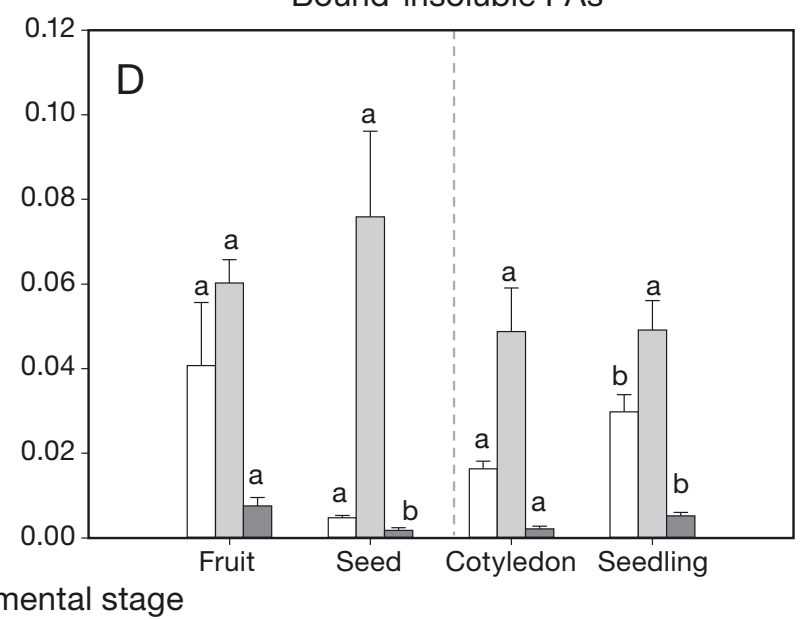

Fig. 2. Cymodocea nodosa. Mean (+SE) endogenous polyamine (PA) concentration during seed and seedling development, including putrescine (Put), spermidine (Spd) and spermine (Spm). (A) Total endogenous PA content; (B) free PA fraction; (C) bound-soluble PA fraction; (D) bound-insoluble PA fraction. Different letters show significant differences between stages of development (i.e. fruit vs. seed and cotyledon vs. seedling, indicated by the dashed line) in each polyamine by unpaired 2-sample $t$-tests $(\mathrm{p} \leq 0.05)$

Table 2. Cymodocea nodosa. Mean $( \pm \mathrm{SE})$ polyamine $(\mathrm{PA})$ concentration, in total and by fraction, and Put $(\mathrm{Spm}+\mathrm{Spd})^{-1} \mathrm{ratio}$ of seedlings during 4 different salinity treatments. Different letters show significant differences between treatments from ANOVA and post hoc tests ( $\mathrm{p} \leq 0.05)$. Put: putrescine; Spd: spermidine; Spm: spermine

\begin{tabular}{|c|c|c|c|c|c|}
\hline \multirow{2}{*}{ Salinity (psu) } & & \multicolumn{3}{|c|}{ PA concentration ( $\mu \mathrm{mol} \mathrm{PA} \mathrm{g}^{-1}$ fresh wt) } & \multirow[t]{2}{*}{ Put $(\mathrm{Spd}+\mathrm{Spm})^{-1}$} \\
\hline & Total & Free & Bound-soluble & Bound-insoluble & \\
\hline 36 & $0.548 \pm 0.016^{\mathrm{a}}$ & $0.178 \pm 0.013^{\mathrm{a}}$ & $0.277 \pm 0.011^{\mathrm{a}}$ & $0.093 \pm 0.010^{\mathrm{a}}$ & $1.659^{\mathrm{a}}$ \\
\hline 18 & $0.530 \pm 0.015^{\mathrm{a}}$ & $0.165 \pm 0.012^{\mathrm{a}}$ & $0.278 \pm 0.003^{\mathrm{a}}$ & $0.087 \pm 0.007^{\mathrm{a}}$ & $1.484^{\mathrm{a}}$ \\
\hline 11 & $0.511 \pm 0.028^{\mathrm{a}}$ & $0.179 \pm 0.013^{\mathrm{a}}$ & $0.242 \pm 0.013^{\mathrm{a}}$ & $0.090 \pm 0.004^{\mathrm{a}}$ & $1.912^{\mathrm{a}}$ \\
\hline 5 & $0.453 \pm 0.038^{\mathrm{a}}$ & $0.159 \pm 0.009^{\mathrm{a}}$ & $0.235 \pm 0.031^{\mathrm{a}}$ & $0.059 \pm 0.003^{b}$ & $1.770^{\mathrm{a}}$ \\
\hline
\end{tabular}

\section{Effect of salinity on seedling content}

PA concentrations followed a similar pattern, with high Put $(\mathrm{Spd}+\mathrm{Spm})^{-1}$ ratios across all salinity levels $(\geq 1.5$, Table 2). However, total PA concentration decreased slightly as salinity decreased (Table 2), showing a significant difference between 5 psu and higher salinities in the bound-insoluble fraction $(\mathrm{p} \leq$ 0.05). Particularly, as shown in Fig. 3, Spm was the most variable PA, showing a significant difference in 


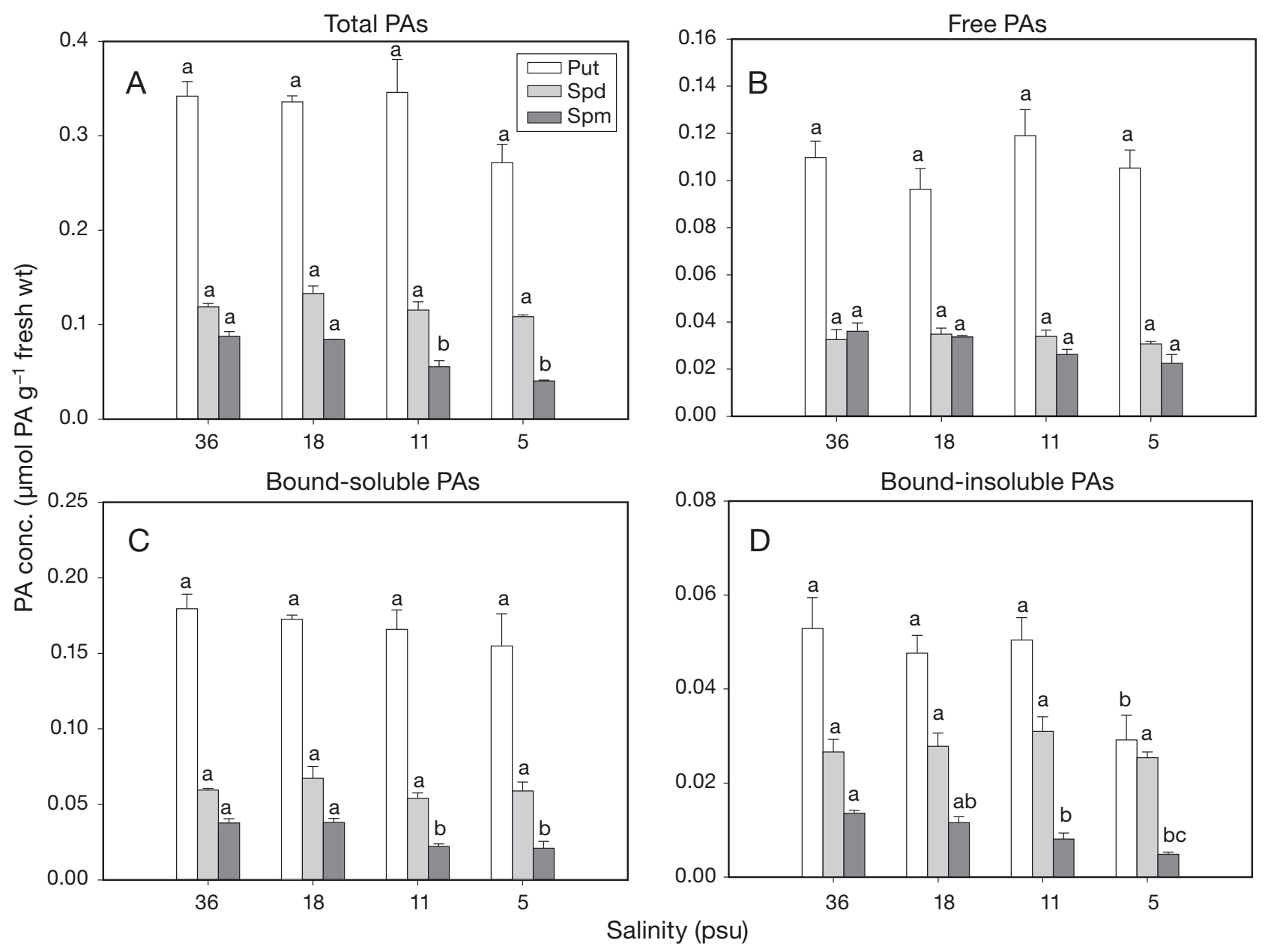

Fig. 3. Cymodoaa nodosa. Mean (+SE) endogenous polyamine (PA) content of seedlings, including putrescine (Put), spermidine (Spd) and spermine (Spm) after $15 \mathrm{~d}$ of different salinity treatments. (A) Total endogenous PA content; (B) free PA fraction; (C) bound-soluble PA fraction; (D) bound-insoluble PA fraction. Different letters show significant differences between treatments in each polyamine by ANOVA and post hoc tests $(\mathrm{p} \leq 0.05)$

bound-soluble and -insoluble fractions (and consequently in total Spm content) between the highest (36 and $18 \mathrm{psu})$ and lowest (11 and 5 psu) salinities. The bound-insoluble Put fraction also decreased significantly at $5 \mathrm{psu}$ in relation to higher salinities (Fig. $3 ; \mathrm{p} \leq 0.05$ ). No significant differences were found in the free PA fraction.

\section{Effect of salinity and Spd application on seedling chlorophyll levels}

$F_{\mathrm{v}} / F_{\mathrm{m}}$ ratio gradually decreased as salinity decreased, thus ANOVA and post hoc tests ( $\mathrm{p} \leq 0.05)$ showed significant differences between lower (5 and $11 \mathrm{psu}$ ) and higher salinities (18 and $36 \mathrm{psu}$ ) with or without Spd (Fig. 4). Chlorophyll fluores-

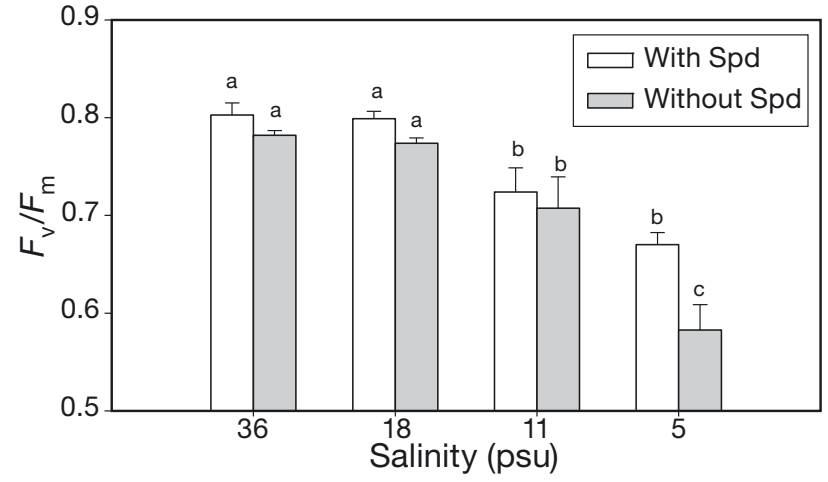

Fig. 4. Cymodocea nodosa. Mean (+SE) chlorophyll fluorescence levels determined by the $F_{\mathrm{v}} / F_{\mathrm{m}}$ ratio of seedlings after salinity treatment $(36,18,11$ and $5 \mathrm{psu})$ and spermidine (Spd) application $\left(10^{-6} \mathrm{M}\right)$ in 3 independent experiments. Different letters show significant differences between treatments by ANOVA and post hoc tests ( $p \leq 0.05$ ) 
cence ranged between maximum $F_{\mathrm{v}} / F_{\mathrm{m}}$ values of $0.8027 \pm 0.012$ (mean $\pm \mathrm{SE}$ ) at highest salinity levels (36 psu), when Spd was exogenously applied (Fig. 4), and minimum values at lowest salinity levels without adding $\operatorname{Spd}\left(F_{\mathrm{v}} / F_{\mathrm{m}}: 0.5828 \pm 0.025\right.$ at $5 \mathrm{psu}$ ). Exogenous application of Spd slightly improved chlorophyll fluorescence levels in all salinity treatments, showing a significant difference in $F_{\mathrm{v}} / F_{\mathrm{m}}$ values at the lowest salinity level (5 psu) (Fig. 4).

\section{DISCUSSION}

PAs are involved in all stages of the plant life cycle, including embryo development and seed germination (Pal Bais \& Ravishankar 2002, Astarita et al. 2003, Puga-Hermida et al. 2003, Urano et al. 2005, Cao et al. 2010, Pieruzzi et al. 2011). Zygotic embryogenesis is a complex process that includes an initial phase characterized by cell division and cell differentiation, followed by a maturation phase where large amounts of storage products are gradually accumulated, leading to seed desiccation and dormancy (Dodeman et al. 1997, Santa-Catarina et al. 2006, Cao et al. 2010). Cymodocea nodosa seeds are defined as recalcitrant (non-desiccation tolerant) but undergo a dormant period that includes physical and physiological aspects, as detailed in previous work (Zarranz et al. 2010b). Several studies have shown correlation between an increase in PA levels with cell division and a drop in PAs during reduction of metabolic activity (Pal Bais \& Ravishankar 2002). This is similar to our results, where PA levels in C. nodosa were high during the early stage of embryonic development, in the initial phase of cellular division (fruit stage; Table 1), and significantly decreased at the seed stage (specifically in the free PA fraction, Table 1), in which the embryo remains in a dormant state. Similar results have been obtained in several previous works. For example, working with the land plant Arabidopsis, Urano et al. (2005) found higher level of PAs in immature than in mature siliques or dry seeds, which indicated that PAs are involved in the early stage of seed development.

The Put $(\mathrm{Spd}+\mathrm{Spm})^{-1}$ ratio has been suggested by several authors as a developmental marker since the highest values have been observed in the early embryo developmental stages (corresponding to cellular multiplication and elongation), followed by a decrease towards the end of embryo development (corresponding to stabilization of the dry matter content) (Astarita et al. 2003, Santa-Catarina et al. 2006).
In our study, total Put and Spm concentration significantly decreased during seed maturation, while total Spd remained constant (Fig. 2A), which caused a drastic decrease in the Put $(\mathrm{Spd}+\mathrm{Spm})^{-1}$ ratio from 0.9537 to 0.1096 (Table 1 ).

Levels of total Spd content remained constant (Fig. 2A), with an increase in bound-soluble and insoluble fractions during seed development (Fig. 2C,D). Paul et al. (1984) also documented an increase in Spd level as seed dry weight accumulation progressed as well as a decrease in Put to a nearly undetectable level, suggesting that Spd synthesis may be of some importance in seed development. More recent studies using Arabidopsis double mutants deficient in PA biosynthetic genes also demonstrated that Spd is an important factor in seed development and that the embryo lethal phenotype in both mutants was due to Spd deficiency (Imai et al. 2004, Urano et al. 2005). According to Cao et al. (2010), higher Spd and Spm might be necessary during later periods of seed development for seeds to successfully germinate and grow into seedlings.

Plant PAs also seem to have a significant role during Cymodocea nodosa seedling development, showing an inverse pattern as described before, with a significant increase in total PA content from cotyledon to seedling stage (Table 1, Fig. 2A-D). This could be related to the fact that they are primarily detected in actively growing tissues, as referred in Hussain et al. (2011). The Put $(\mathrm{Spm}+\mathrm{Spd})^{-1}$ ratio also increased, due to a higher increase in Put levels and the more constant levels in total Spd content (Table 1, Fig. 2). Several authors have previously related this ratio with seed germination, showing an increase in at least the first stages of development (Dias et al. 2009, Pieruzzi et al. 2011).

Seagrasses are marine plants that have evolved from terrestrial ancestors, and have developed a number of mechanisms to tolerate high salinity levels (Kuo \& den Hartog 2001, Orth et al. 2006, Wissler et al. 2011). An excessive presence of $\mathrm{Na}^{+}$and $\mathrm{Cl}^{-}$ions within the cytoplasm could be toxic and lead to cell death, so adaptive mechanisms are based on osmotic adjustments, which include the localization of toxic ions into vacuoles and the presence of organic compounds and low molecular weight chaperones that serve as osmoprotectants (Touchette 2007). Several studies have focused on understanding the physiological mechanisms that halophyte plants have developed to tolerate high salinity concentrations (Breckle 2002, Touchette 2007, Flowers \& Colmer 2008, Türkan \& Demiral 2009). However, very few have focused on the necessity of salt for plant devel- 
opment or the maintenance of halophytic status in plants. Barbour (1970) defined the term 'obligate halophyte' as plants with optimal growth at moderate or high salinity and incapable of growth at low salinity. Cymodocea nodosa may therefore be defined as an 'obligate halophyte', since not only has it developed mechanisms to tolerate salt, but it also requires a stable environment with relatively high salinity for its survival, as can be seen in our study when salinity conditions reached $11 \mathrm{psu}$, and particularly 5 psu, as discussed below. The majority of seagrass species are 'obligate halophytes' but have not been catalogued in this regard. Although some of them can tolerate wide ranges of salinity, such as Zostera noltii and Halophila ovalis (Ralph 1998, Fernández Torquemada \& Sánchez Lizaso 2006), only Ruppia maritima has been classified as a 'non-obligate halophyte', as it is able to adapt permanently to freshwater through its ability to osmoregulate (Murphy et al. 2003).

The $F_{\mathrm{v}} / F_{\mathrm{m}}$ ratio is commonly used as a sensitive indicator of plant photosynthetic performance, with normal values for most plant species ranging from 0.7 to 0.8 . Thus, only severe stress would cause a significant reduction in this parameter (Maxwell \& Johnson 2000, Ritchie 2006). Several studies have demonstrated a decrease in $F_{\mathrm{v}} / F_{\mathrm{m}}$ ratio and the consecutive inhibition of photosynthetic performance on different seagrass species exposed to extreme hypo- or hyperosmotic conditions (Ralph 1998, Beer et al. 2006, Kahn \& Durako 2006, Koch et al. 2007, Pagès et al. 2010). In the present study, levels of chlorophyll fluorescence ranged between 0.8 and 0.7 in the highest salinity treatment, showing no effect on seedling vitality (Fig. 4). Conversely, the $F_{\mathrm{v}} / F_{\mathrm{m}}$ ratio decreased from $11 \mathrm{psu}$ onwards to reach minimum values at 5 psu $(0.582 \pm 0.025$; mean $\pm \mathrm{SE})$, indicating that seedlings were under high stress. This decline in the photosynthetic activity caused by hypo-osmotic shock has been attributed to a decline in cellular ion content, including the ions necessary as photosynthetic cofactors (Lapointe et al. 1984, Simon et al. 1999). In that sense, exogenous application of Spd as the constant PA during seedling development significantly improved $F_{\mathrm{v}} / F_{\mathrm{m}}$ values at 5 psu $(0.670 \pm 0.012)$, suggesting the protective role of Spd in maintaining the photosynthetic apparatus of Cymodocea nodosa seedlings under long term hypo-osmotic stress. According to Ioannidis \& Kotzabasis (2007), PAs, which are normally found in chloroplasts of higher plants, are able to restore the effectiveness in PSII efficiency $\left(F_{\mathrm{v}} / F_{\mathrm{m}}\right)$, especially in the higher polycationic amines (Spm and Spd). In that sense, exogenous application of PAs has also served to mitigate the effects of different stresses in terrestrial plants and improve the photosynthetic functions by binding to the thylakoid membranes (Demetriou et al. 2007, Ioannidis \& Kotzabasis 2007, Farooq et al. 2009, Zhang et al. 2009). More recently, Hamdani et al. (2011) studied how PAs interact with thylakoid proteins during stress and concluded that PAs not only conjugate with LHC polypeptides, but also interact with extrinsic proteins and the hydrophilic part of intrinsic proteins of PSII by electrostatic interaction, which could stabilize the conformation of proteins under various stresses.

Terrestrial plants tend to accumulate PAs in response to different abiotic stresses, including salinity, drought and temperature among others, that enable plants to adapt and protect themselves from these external factors (Pang et al. 2007, Hussain et al. 2011). According to recent studies, the expression of ADC1 and ADC2 genes, responsible for PA biosynthesis, are strongly induced by these abiotic stresses (Hussain et al. 2011 and references therein). In the case of the red marine alga Grateloupia imbricate, hypo-saline conditions caused the accumulation of PAs in the free fraction due to a decrease in transglutaminase activity (as G. doryphora, GarcíaJiménez et al. 2007). Therefore, Cymodocea nodosa would be expected to react similarly, accumulating PAs in response to long-term osmotic stress or changing their distributional patterns (from the free to the bound fraction, and vice versa); however, in the present work total PA concentration in C. nodosa decreased slightly as salinity decreased (Table 2, Fig. 3), showing a significant difference between 5 psu and higher salinities in bound-insoluble PAs. This might be due to disruption in PA route biosynthesis (arginine and ornithine pathways, KaurSawhney et al. 2003), which may cause the synthesis of Put, Spd and Spm to cease. This result further supports C. nodosa as an 'obligate-halophyte' that needs marine salt to live, as apparently it has not developed the necessary mechanisms to defend against low salinities, or at least, those mechanisms concerning the production and accumulation of PAs. To reinforce this view, we observed the presence of the diamine Cad in the lowest salinity treatment $(5 \mathrm{psu})$, with a total Cad content of $0.089 \pm 0.016 \mu \mathrm{mol} \mathrm{PA} \mathrm{g}{ }^{-1}$ fresh wt $(0.034 \pm 0.006,0.047 \pm 0.013$ and $0.008 \pm 0.003 \mu \mathrm{mol}$ PA $\mathrm{g}^{-1}$ fresh wt in the free, bound-soluble and bound-insoluble Cad fractions, respectively), which is produced from the decarboxylation of the amino acid lysine by the enzyme lysine decarboxylase (Kuznetsov et al. 2007, Pang et al. 2007). The presence of this PA is indicative of cell death and failure of the mechanisms to adapt to hypo-osmotic stress. Even if 
we have not conducted an exhaustive and systematic biometric study of seedlings, the following aspects could be noticed: the loss of vigor, leaf browning and the consecutive death of plants at the lowest 5 psu salinity level. Murphy et al. (2003) also observed a decrease in proline and carbohydrate levels in response to low salinity in Ruppia maritima. However, solute concentrations recovered after $6 \mathrm{~d}$, suggesting a change in metabolism or leaf water content in response to this low-salinity experiment. This recovery may reflect the non-obligatory halophytic nature of $R$. maritima, since, after physiological adjustments, the plants were able to overcome the stress and become permanently adapted to freshwater, which would not occur in the case of Cymodocea nodosa.

In conclusion, Cymodocea nodosa contains active endogenous PAs that varied according to the stage of development, showing their important role during seed and seedling development. A long-term decrease in salinity from 11 to 5 psu caused irreversible changes in the physiology of C. nodosa, including a reduction in total endogenous PA content and in the photosynthetic efficiency, showing that this species is not adapted to permanent changes in low salinity. This affirms the status of C. nodosa as an 'obligate halophyte'.

\section{LITERATURE CITED}

Amooaghaie R (2011) Role of polyamines in the tolerance of soybean to water deficit stress. World Acad Sci Eng Technol 80:498-502

> Amooaghaie R, Moghym S (2011) Effect of polyamines on thermotolerance and membrane stability of soybean seedling. Afr J Biotechnol 10:9673-9679

> Astarita LV, Handro W, Floh EIS (2003) Changes in polyamines content associated with zygotic embryogenesis in the Brazilian pine, Araucaria angustifolia (Bert.) O. Ktze. Rev Bras Bot 26:163-168

Balestri E, Bertini S (2003) Growth and development of Posidonia oceanica seedlings treated with plant growth regulators: possible implications for meadow restoration. Aquat Bot 76:291-297

> Barbour MG (1970) Is any angiosperm an obligate halophyte? Am Midl Nat 84:105-120

> Baron K, Stasolla C (2008) The role of polyamines during in vivo and in vitro development. In Vitro Cell Dev Biol Plant 44:384-395

> Beer S, Mtolera M, Lyimo T, Björk M (2006) The photosynthetic performance of the tropical seagrass Halophila ovalis in the upper intertidal. Aquat Bot 84:367-371

Breckle SW (2002) Salinity, halophytes and salt affected natural ecosystems. In: Läuchli A, Lüttge U (eds) Salinity: environment-plants-molecules. Kluwer Academic, Dordrecht, p 53-77

Cao DD, Hu J, Zhu SJ, Hu WM, Knapp A (2010) Relationship between changes in endogenous polyamines and seed quality during development of $s h_{2}$ sweet corn (Zea mays L.) seed. Sci Horto 123:301-307

> Caye G, Meinesz A (1986) Experimental study of seed germination in the seagrass Cymodocea nodosa. Aquat Bot 26:79-87

- Caye G, Bulard C, Meinesz A, Loquès F (1992) Dominant role of seawater osmotic pressure on germination in Cymodocea nodosa. Aquat Bot 42:187-193

Chollett I, Bone D, Pérez D (2007) Effects of heavy rainfall on Thalassia testudinum beds. Aquat Bot 87:189-195

> Demetriou G, Neonaki C, Navakoudis E, Kotzabasis K (2007) Salt stress impact on the molecular structure and function of the photosynthetic apparatus - the protective role of polyamines. Biochim Biophys Acta 1767:272-280

Dias LLC, Santa-Catarina C, Silveira V, Pieruzzi FP, Floh EIS (2009) Polyamines, amino acids, IAA and ABA contents during Ocotea catharinensis seed germination. Seed Sci \& Technol 37:42-51

Dodeman VL, Ducreux G, Kreis M (1997) Zygotic embryogenesis versus somatic embryogenesis. J Exp Bot 48: 1493-1509

> Farooq M, Wahid A, Lee DJ (2009) Exogenously applied polyamines increase drought tolerance of rice by improving leaf water status, photosynthesis and membrane properties. Acta Physiol Plant 31:937-945

Fernández-Torquemada Y, Sánchez-Lizaso JL (2005) Effects of salinity on leaf growth and survival of the Mediterranean seagrass Posidonia oceanica (L.) Delile. J Exp Mar Biol Ecol 320:57-63

Fernández Torquemada Y, Sánchez Lizaso JL (2006) Effects of salinity on growth and survival of Cymodocea nodosa (Ucria) Ascherson and Zostera noltii Hornemann. Biol Mar Mediterr 13:46-47

> Flowers TJ, Colmer TD (2008) Salinity tolerance in halophytes. New Phytol 179:945-963

- García-Jiménez P, Navarro EP, Santana CH, Luque Á, Robaina RR (2006) Anatomical and nutritional requirements for induction and sustained growth in vitro of $\mathrm{Cy}$ modocea nodosa (Ucria) Ascherson. Aquat Bot 84:79-84

> García-Jiménez P, Just PM, Delgado AM, Robaina RR (2007) Transglutaminase activity decrease during acclimation to hyposaline conditions in marine seaweed Grateloupia doryphora (Rhodophyta. Halymeniaceae). J Plant Physiol 164:367-370

Gupta S, Gupta NK (2011) Field efficacy of exogenously applied putrescine in wheat (Triticum aestivum) under water-stress conditions. Indian J Agric Sci 81:516-519

Hamdani S, Yaakoubi H, Carpentier R (2011) Polyamines interaction with thylakoid proteins during stress. J Photochem Photobiol B 104:314-319

Hellblom F, Björk M (1999) Photosynthetic responses in Zostera marina to decreasing salinity, inorganic carbon content and osmolality. Aquat Bot 65:97-104

Hussain SS, Ali M, Ahmad M, Siddique KHM (2011) Polyamines: natural and engineered abiotic and biotic stress tolerance in plants. Biotechnol Adv 29:300-311

Imai A, Matsuyama T, Hanzawa Y, Akiyama T and others (2004) Spermidine synthase genes are essential for survival of Arabidopsis. Plant Physiol 135:1565-1573

- Ioannidis NE, Kotzabasis K (2007) Effects of polyamines on the functionality of photosynthetic membrane in vivo and in vitro. Biochim Biophys Acta 1767:1372-1382 
Irlandi E, Orlando B, Maciá S, Biber P, Jones T, Kaufman L, Lirman D, Patterson ET (2002) The influence of freshwater runoff on biomass, morphometrics, and production of Thalassia testudinum. Aquat Bot 72:67-78

Kahn AE, Durako MJ (2006) Thalassia testudinum seedling responses to changes in salinity and nitrogen levels. J Exp Mar Biol Ecol 335:1-12

Kaur-Sawhney R, Tiburcio AF, Altabella T, Galston AW (2003) Polyamines in plants: an overview. J Cell Mol Biol 2:1-12

Koch MS, Schopmeyer SA, Kyhn-Hansen C, Madden CJ, Peters JS (2007) Tropical seagrass species tolerance to hypersalinity stress. Aquat Bot 86:14-24

Kuo J, den Hartog C (2001) Seagrass taxonomy and identification key. In: Short FT, Coles RG (eds) Global seagrass research methods. Elsevier, Amsterdam, p 31-58

Kuo J, den Hartog C (2006) Seagrass morphology, anatomy, and ultrastructure. In: Larkum AWD, Orth RJ, Duarte CM (eds) Seagrasses: biology, ecology and conservation. Springer Verlag, Dordrecht, p 51-87

Kuznetsov VV, Radyukina NL, Shevyakova NI (2006) Polyamines and stress: biological role, metabolism, and regulation. Russ J Plant Physiol 53:583-604

Kuznetsov VV, Shorina M, Aronova E, Stetsenko L, Rakitin V, Shevyakova N (2007) NaCl- and ethylene-dependent cadaverine accumulation and its possible protective role in the adaptation of the common ice plant to salt stress. Plant Sci 172:363-370

Lapointe BE, Rice DL, Lawrence JM (1984) Responses of photosynthesis, respiration, growth and cellular constituents to hypo-osmotic shock in the red alga Gracilaria tikvahiae. Comp Biochem Physiol A 77: 127-132

Lin PPC, Egli DB, Li GM, Meckel L (1984) Polyamine titer in the embryonic axis and cotyledons of Glycine max (L.) during seed growth and maturation. Plant Physiol 76: 366-371

Marcé M, Brown DS, Capell T, Figueras X, Tiburcio AF (1995) Rapid high-performance liquid chromatographic method for the quantitation of polyamines as their dansyl derivatives: application to plant and animal tissues. J Chromatogr B 666:329-335

- Marián FD, García-Jiménez P, Robaina RR (2000) Polyamine levels in the seagrass Cymodocea nodosa. Aquat Bot 68: 179-184

Maxwell K, Johnson GN (2000) Chlorophyll fluorescencea practical guide. J Exp Bot 51:659-668

> Murphy LR, Kinsey ST, Durako MJ (2003) Physiological effects of short-term salinity changes on Ruppia maritima. Aquat Bot 75:293-309

> Mutlu F, Bozcuk S (2007) Relationship between salt stress and levels of free and bound polyamines in sunflower plants. Plant Biosyst 141:31-39

> Orth RJ, Carruthers TJB, Dennison WC, Duarte CM and others(2006) A global crisis for seagrass ecosystems. Bioscience 56:987-996

> Pagès JF, Pérez M, Romero J (2010) Sensitivity of the seagrass Cymodocea nodosa to hypersaline conditions: a microcosm approach. J Exp Mar Biol Ecol 386:34-38

Pal Bais H, Ravishankar GA (2002) Role of polyamines in the ontogeny of plants and their biotechnological applications. Plant Cell Tissue Organ Cult 69:1-34

Pang XM, Zhang ZY, Wen XP, Ban Y, Moriguchi T (2007)
Polyamine, all-purpose players in response to environment stresses in plants. Plant Stress 1:173-188

$>$ Pieruzzi FP, Dias LLC, Balbuena TS, Santa-Catarina C, dos Santos ALW, Floh EIS (2011) Polyamines, IAA and ABA during germination in two recalcitrant seeds: Araucaria angustifolia (Gymnosperm) and Ocotea odorifera (Angiosperm). Ann Bot 108:337-345

Provasoli L (1968) Media and prospects for cultivation of marine algae. In: Watanabe A, Hattori A (eds) Cultures and collections of algae. Japanese Society of Plant Physiologists, Tokyo, p 47-74

Puga-Hermida MI, Gallardo M, Matilla AJ (2003) The zygotic embryogenesis and ripening of Brassica rapa seeds provokes important alterations in the levels of free and conjugated abscisic acid and polyamines. Physiol Plant 117:279-288

Ralph PJ (1998) Photosynthetic responses of Halophila ovalis (R. Br.) Hook. f. to osmotic stress. J Exp Mar Biol Ecol 227:203-220

Ralph PJ (1999) Photosynthetic response of Halophila ovalis (R. Br.) Hook. $f$. to combined environmental stress. Aquat Bot 65:83-96

Ritchie GA (2006) Chlorophyll fluorescence: What is it and what do the numbers mean? In: Riley LE, Dumroese RK, Landis TD (eds) National Proceedings: Forest and Conservation Nursery Associations - 2005. Proc RMRS-P-43. Rocky Mountain Research Station, Forest Service, US Dept Agriculture, Fort Collins, CO. Available at: www. fs.fed.us/rm/pubs/rmrs_p043/rmrs_p043_034_042.pdf

Sacramento AT, García-Jiménez P, Robaina RR (2007) The polyamine spermine induces cystocarp development in the seaweed Grateloupia (Rhodophyta). Plant Growth Regul 53:147-154

Sánchez-Lizaso JL, Romero J, Ruiz J, Gacia E and others (2008) Salinity tolerance of the Mediterranean seagrass Posidonia oceanica: recommendations to minimize the impact of brine discharges from desalination plants. Desalination 221:602-607

Santa-Catarina C, Silveira V, Balbuena TS, Viana AM, Estelita MEM, Handro W, Floh EIS (2006) IAA, ABA, polyamines and free amino acids associated with zygotic embryo development of Ocotea catharinensis. Plant Growth Regul 49:237-247

> Simon C, Gall EA, Levavasseur G, Deslandes E (1999) Effects of short-term variations of salinity and temperature on the photosynthetic response of the red alga Grateloupia doryphora from Brittany (France). Bot Mar 42: $437-440$

> Terrados Muñoz J (1995) Effects of some plant growth regulators on the growth of the seagrass Cymodocea nodosa (Ucria) Ascherson. Aquat Bot 51:311-318

> Touchette BW (2007) Seagrass-salinity interactions: physiological mechanisms used by submersed marine angiosperms for a life at sea. J Exp Mar Biol Ecol 350:194-215

> Türkan I, Demiral T (2009) Recent developments in understanding salinity tolerance. Environ Exp Bot 67:2-9

Urano K, Hobo T, Shinozaki K (2005) Arabidopsis ADC genes involved in polyamine biosynthesis are essential for seed development. FEBS Lett 579:1557-1564

> Wissler L, Codoñer FM, Gu J, Reusch TBH, Olsen JL, Procaccini G, Bornberg-Bauer E (2011) Back to the sea twice: identifying candidate plant genes for molecular 
evolution to marine life. BMC Evol Biol 11:8

Yang HY, Shi GX, Qiao XQ, Tian XL (2011) Exogenous spermidine and spermine enhance cadmium tolerance of Potamogeton malaianus. Russ J Plant Physiol 58: 622-628

Yiu JC, Liu CW, Fang DY, Lai YS (2009) Waterlogging tolerance of Welsh onion (Allium fistulosum L.) enhanced by exogenous spermidine and spermine. Plant Physiol Biochem 47:710-716

Zarranz ME, González-Henríquez N, García-Jiménez P, Robaina RR (2010a) Restoration of Cymodocea nodosa seagrass meadows through seed propagation: germination in vitro, seedling culture and field transplants. Bot Mar 53:173-181

Editorial responsibility: Brant Touchette,

Elon, North Carolina, USA
Zarranz ME, González-Henríquez N, García-Jiménez P, Robaina RR (2010b) Restoration of Cymodocea nodosa (Uchria) Ascherson seagrass meadows through seed propagation: seed storage and influences of plant hormones and mineral nutrients on seedling growth in vitro. Bot Mar 53:439-448

Zhang RH, Li J, Guo SR, Tezuka T (2009) Effects of exogenous putrescine on gas-exchange characteristics and chlorophyll fluorescence of $\mathrm{NaCl}$-stressed cucumber seedlings. Photosynth Res 100:155-162

Zhou Q, Yu B (2010) Changes in content of free, conjugated and bound polyamines and osmotic adjustment in adaptation of vetiver grass to water deficit. Plant Physiol Biochem 48:417-425

Submitted: March 9, 2012; Accepted: June 15, 2012

Proofs received from author(s): September 20, 2012 